\title{
Dietary zinc requirement of Siberian sturgeon (Acipenser baerii, Brandt 1869) juveniles, based on the growth performance and blood parameters
}

\author{
Kadusa Moazenzadeh • Houman Rajabi Islami • Abasali Zamini • \\ Mehdi Soltani
}

Received: 23 July 2016/ Accepted: 11 January 2017/Published online: 23 January 2017

(c) The Author(s) 2017. This article is published with open access at Springerlink.com

\begin{abstract}
This study investigated the effect of dietary $\mathrm{Zn}$ levels on growth performance, feed utilization, and hematological parameters of juvenile Siberian sturgeon (Acipenser baerii, Brandt 1869). The five semipurified diets were formulated by adding $0,5,10,20$, and $40 \mathrm{mg} \mathrm{Zn} \mathrm{kg}{ }^{-1}$ diet in the form of zinc sulfate $\left(\mathrm{ZnSO}_{4}\right)$ to provide the actual dietary value of $14.7,20.8,27.3,37.7$, and $46.4 \mathrm{Zn} \mathrm{kg}^{-1}$ diet, respectively. The results showed that dietary $\mathrm{Zn}$ elevating level significantly improved the growth and feed utilization of the fish $(p<0.05)$, but not the hepatosomatic index $(p>0.05)$. Erythrocyte number, hemoglobin concentration, and hematocrit were increased with raising dietary $\mathrm{Zn}$ level $(p<0.05)$, whereas a regular trend was not observed in blood indices, including MCV, MCH, and MCHC. A significant increase was also found in the leucocyte number followed by their differential counts, except for eosinophil percentage. The broken line regression model indicated optimal dietary $\mathrm{Zn}$ level for growth maximization of fish was estimated to be $29.15 \mathrm{mg} \mathrm{Zn}$ $\mathrm{kg}^{-1}$ diet. In spite of well correlation with dietary $\mathrm{Zn}$ level, no break point was observed to estimate the juvenile Siberian sturgeon requirement based on the erythrocyte numbers.
\end{abstract}

Keywords Zinc $\cdot$ Erythrocyte $\cdot$ Leucocyte $\cdot$ Blood parameters $\cdot$ Growth performance $\cdot$ Acipenser baerii

$\begin{array}{ll}\text { Abbreviations } \\ \text { FW } & \text { Final weight } \\ \text { SGR } & \text { Specific growth rate } \\ \text { FCR } & \text { Food conversion ratio } \\ \text { CF } & \text { Condition factor } \\ \text { HSI } & \text { Hepatosomatic index } \\ \text { RBC } & \text { Red blood cell } \\ \text { WBC } & \text { White blood cell }\end{array}$

K. Moazenzadeh · H. R. Islami

Department of Fisheries, Science and Research Branch, Islamic Azad University, P.O. Box: 14515-775, Tehran, Iran

H. R. Islami $(\bowtie)$

Department of Fisheries, College of Agricultural and Natural Resources, Science and Research Branch, Islamic Azad

University, Islamic Azad University Square, Sattari Avenue, Tehran 1477893855, Iran

e-mail: rajabi.h@srbiau.ac.ir

A. Zamini

Department of Fisheries, Lahijan Branch, Islamic Azad University, Lahijan, Iran

M. Soltani

Department of Aquatic Animal Health, Faculty of Veterinary, University of Tehran, Tehran, Iran 
$\mathrm{Hb} \quad$ Hemoglobin

HCT Hematocrit

MCV Mean corpuscular volume

$\mathrm{MCH}$ Mean cell hemoglobin

MCHC Mean corpuscular hemoglobin concentration

\section{Introduction}

Zinc $(\mathrm{Zn})$ is an essential micro-mineral required for various metabolic pathways, including growth, protein synthesis, energy metabolism, and immunity of animals, including fish (Houng-Yung et al. 2014; Lin et al. 2013). Zinc also serves as a functional cofactor for more than 200 metalloenzymes, such as superoxide dismutase, RNA polymerase, alkaline phosphatase, alcohol dehydrogenase, and carbonic anhydrase (Kucukbay et al. 2006; Fountoulaki et al. 2010; Luo et al. 2011; Liang et al. 2012; Lin et al. 2013). The importance of $\mathrm{Zn}$ in the antioxidant protection has been also illustrated in many aquatic organisms (Huang et al. 2015; Feng et al. 2011; Trevisan et al. 2014).

Although fish can uptake the $\mathrm{Zn}$ directly from the surrounding water via the gills, ambient waterborne $\mathrm{Zn}$ concentration in most freshwaters is known to be suboptimal to meet their metabolic requirements and a dietary supplementation is necessary to compensate for low dietborne $\mathrm{Zn}$ concentration (Gatlin and Phillips 1989; Fountoulaki et al. 2010; Luo et al. 2011). On the other hand, excessive $\mathrm{Zn}$ in the diet has been reported to compete with the absorption of other bivalent elements, including copper $(\mathrm{Cu})$, iron $(\mathrm{Fe})$, calcium $(\mathrm{Ca})$, and cadmium (Cd) (Clearwater et al. 2002). Quantification of environmental quality parameters provides only limited information on the substances present in the environment aquatic and gives no information on the relationship between contaminant exposure and biological effects in aquatic organisms; therefore, the impact of pollutants by biomarkers becomes of relevant interest (Fazio et al. 2012, 2013; Chromcova et al. 2015). High $\mathrm{Zn}$ ingestion also reduces growth and feed utilization as the cause of appetite loss in Nile tilapia, Oreochromis niloticus (Do Carmo et al. 2004), Jian carp, Cyprinus carpio var. Jian (Tan et al. 2011), and juvenile yellow catfish, Pelteobagrus fulvidraco (Luo et al. 2011). Hence, dietary Zn level should be in an optimal range which can decrease the feed cost and prevent mineral leaching in aquatic environments (Buentello et al. 2009; Huang et al. 2015).

The dramatic reduction in sturgeon populations due to overfishing, poaching, pollution, and habitat alteration has led to the inevitability of commercial aquaculture as a tool for decreasing pressure on wild fish stocks as well as caviar and meat production (Beamesderfer and Farr 1997; Waldman and Wirgin 1997; Williot et al. 2002; Chebanov et al. 2002). The Siberian sturgeon (Acipenser baerii) is a one of the freshwater fish species which natively distributed in the major Siberian Rivers draining to the Kara, Laptev, and East Siberian seas (Bronzi et al. 2011; Wei et al. 2011). Fast growth rate during early life stages and strong adaptability properties to various climatic zones made the Siberian sturgeon a suitable candidate for aquaculture throughout the world (Hamlin et al. 2006; Abdolahnejad et al. 2015).

To date, numerous researches have been aimed to quantify dietary $\mathrm{Zn}$ requirement in fish, including 26-29 mg kg $\mathrm{mg}^{-1}$ diet for hybrid tilapia, O. niloticus $\times$ O. aureus (Lin et al. 2008), 28.9-33.7 mg kg $\mathrm{miet}^{-1} \mathrm{dor}^{-}$

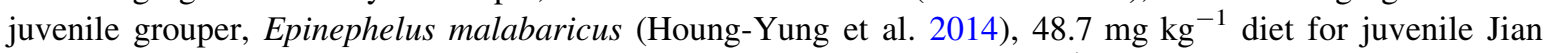
carp, C. carpio var. Jian carp (Tan et al. 2011), and $55.1 \mathrm{mg} \mathrm{kg}^{-1}$ diet for juvenile grass carp, Ctenopharyngodon idella (Liang et al. 2012). Most of these recommendations have been established based on the growth performance, feed utilization, tissue concentration, and enzymatic activities. However, scare information is available regarding the $\mathrm{Zn}$ requirement for improvement of blood parameters in fish species under culture conditions. Accordingly, the aim of the present study was to evaluate the effects of elevated zinc levels on growth performance, feed utilization, and hematological parameters of juvenile Siberian sturgeon (Acipenser baerii, Brandt 1869). 


\section{Materials and methods}

\section{Experimental diets}

The formulation and proximate composition analysis of the basal diet is presented in Table 1. Casein, gelatin, and fish meal were used as dietary protein sources $\left(51.0 \mathrm{~g}\right.$ crude protein $\mathrm{kg}^{-1}$ diet). Corn oil and Kilka fish oil were used as the main dietary lipid source (11.6 $\mathrm{g}$ crude lipid $\mathrm{kg}^{-1}$ diet). Wheat flour, dextrin, and corn starch were also used as the carbohydrate source $\left(26.0 \mathrm{~g}\right.$ crude carbohydrate $\mathrm{kg}^{-1}$ diet $)$.

The five isonitrogenous, isolipidic, and isoenergetic semi-purified diets were formulated to contain increasing levels of supplemental zinc $\left(0,5,10,20\right.$, and $\left.40 \mathrm{mg} \mathrm{Zn} \mathrm{kg}^{-1}\right)$ in the form of hydrated zinc sulfate $\left(\mathrm{ZnSO}_{4} \cdot 5 \mathrm{H}_{2} \mathrm{O}\right)$ at the expense of Alpha cellulose, respectively. Final dietary $\mathrm{Zn}$ concentrations were determined using a flame atomic absorption photometer (AA-6800; Shimadzu, Kyoto, Japan) after acid digestion equaling 14.7 (0), 20.8, 27.3, 37.7, and $46.4 \mathrm{mg} \mathrm{Zn} \mathrm{kg}^{-1}$ in the corresponding diets, respectively.

For the formulation of the experimental diets, all dry ingredients were weighed and mixed thoroughly for $30 \mathrm{~min}$ in a food mixer. Pre-blended premix of fish oil and corn oil was then added slowly while mixing of the ingredients continued for another $30 \mathrm{~min}$. Afterward, $\mathrm{ZnSO}_{4} \cdot 5 \mathrm{H}_{2} \mathrm{O}$ was dissolved in double distilled water and mixed well with the other ingredients to form wet dough. The corresponsive of $\mathrm{ZnSO}_{4} \cdot 5 \mathrm{H}_{2} \mathrm{O}$ corresponding to each diet was dissolved in double distilled water and mixed well with the other diet ingredients until stiff dough resulted. The dough was then passed through a pelletizer having a die of $2 \mathrm{~mm}$ diameter and dried at $30{ }^{\circ} \mathrm{C}$ in drier for $24 \mathrm{~h}$ (Hidalgo et al. 2002). The pellets were then packed, sealed, and stored at $-20{ }^{\circ} \mathrm{C}$ until used.

Fish and experimental conditions

The bioassay was done in the Shahid Dr. Beheshti Reproduction and Rearing Center, Rasht (SDBRRC), Iran. At the beginning of the experiment, a total number of 300 Siberian sturgeon juveniles (Acipenser baerii), with initial body weight of $26.52 \pm 0.94 \mathrm{~g}$ (mean $\pm \mathrm{SD}$ ), were separately stocked in group of 20 uniform-sized

Table 1 Diet formulation and proximate analysis of the basal diet for Siberian sturgeon (Acipenser baerii) juveniles

\begin{tabular}{lc}
\hline Ingredients & $\mathrm{g} \mathrm{kg}^{-1} \mathrm{dry}^{\text {weight diet }}$ \\
\hline Casein & 380 \\
Gelatin & 80 \\
Fish meal & 50 \\
Wheat flour & 110 \\
Dextrin & 70 \\
Corn starch & 110 \\
Corn oil & 60 \\
Fish oil & 60 \\
Vitamin premix ${ }^{1}$ & 2 \\
Mineral premix & 1 \\
Alpha cellulose & 1 \\
Chemical analysis & 4 \\
Crude protein & \\
Crude lipid & 510 \\
Crude carbohydrate & 116 \\
\hline
\end{tabular}

1 Vitamin premix (mg kg ${ }^{-1}$ diet): thiamin, $15 \mathrm{mg}$; riboflavin, $30 \mathrm{mg}$; pyridoxine, $15 \mathrm{mg}$; cobalamin, $0.05 \mathrm{mg}$; niacin, $175 \mathrm{mg}$; folate, $5 \mathrm{mg}$; ascorbic acid, $500 \mathrm{mg}$; inositol, $1000 \mathrm{mg}$; biotin, $2.5 \mathrm{mg}$; calcium pantothenate, $50 \mathrm{mg}$; choline chloride, $2000 \mathrm{mg}$; DL-alpha tocopherol acetate, $60 \mathrm{IU}$; DL-cholecalciferol, $3000 \mathrm{IU}$; and cellulose was used as the carrier

${ }^{2}$ Mineral premix ( $\mathrm{Zn}$ free; $\mathrm{g} \mathrm{kg}^{-1}$ ): calcium carbonate $(40 \% \mathrm{Ca}), 2.15 \mathrm{~g}$; magnesium oxide $(60 \% \mathrm{Mg}), 1.24 \mathrm{~g}$; ferric citrate, $0.2 \mathrm{~g}$; potassium iodide $(75 \% \mathrm{I}), 0.4 \mathrm{mg}$; cupric sulfate, $300 \mathrm{mg}$; manganese sulfate $(33 \% \mathrm{Mn}), 0.3 \mathrm{~g}$; dibasic calcium phosphate $(20 \% \mathrm{Ca}, 18 \% \mathrm{P}), 5 \mathrm{~g}$; cobalt sulfate, $2 \mathrm{mg}$; sodium selenite $(30 \% \mathrm{Se}), 3 \mathrm{mg}$; potassium chloride, $0.9 \mathrm{~g}$; sodium chloride, $0.4 \mathrm{~g}$; and cellulose was used as the carrier 
specimens to fifteen 500-L fiberglass tanks each containing $300 \mathrm{~L}$ freshwater. Each experimental diet was assigned to three tanks in a completely randomized design. Fish were acclimatized to the experimental condition for 2 weeks prior to the feeding trial and hand-fed with the basal diet (without $\mathrm{Zn}$ supplementation) to apparent satiation for Zn-depletion from the body reserves. Filtered water of the Sefidroud River was flowed through each tank to replace the whole tank water every $12 \mathrm{~h}$. All fish groups were fed on the corresponding diets to apparent satiation two times a day for a period of 8 weeks. Fish consumed the respective diet in less than $2 \mathrm{~min}$, and therefore, leaching of $\mathrm{Zn}$ to the rearing water was negligible. Tanks were carefully cleaned every other week to minimize algae and fungal growth at the same time with fish weaning for adjustment of daily feeding ratio.

During the acclimatization and experimental periods, the water conditions were kept at the appropriate range for Siberian sturgeon maintenance (average water temperature $14.5 \pm 0.4{ }^{\circ} \mathrm{C}$, oxygen concentration $7.43 \pm 0.25 \mathrm{mg} \mathrm{L}^{-1}$, pH $7.6 \pm 0.2$, alkalinity $247.5 \pm 3.8 \mathrm{mg} \mathrm{L}^{-1}$, total hardness $320.3 \pm 14.3 \mathrm{mg} \mathrm{L}^{-1}$, and $\mathrm{NH}_{4} 0.14 \pm 0.01 \mathrm{mg} \mathrm{L}^{-1}$ ). Natural photoperiod (approximately 10:14 light/dark) was maintained during the experimental period. Throughout the experimental period, the $\mathrm{Zn}$ concentration in the river water ranged from 0.0073 to $0.0217 \mu \mathrm{g} \mathrm{Zn} \mathrm{L}{ }^{-1}$ without significant difference between the tank water $(p<0.05)$. All physico-chemical analysis were performed with DR 1900 portable spectrophotometer (Hach, Loveland, CO, USA) except for $\mathrm{pH}$ and Temperature which had been measured using portable AP110 pH Meter (Fisher Scientific, Pittsburgh, PA, USA) and temperature meter (YSI incorporated, Yellow Springs, OH, USA).

Sample collection

Fish in each experimental tank were anesthetized with clove oil, Syzygium aromaticum $(0.070$ ppm; Kouřil et al. 2003) after $24 \mathrm{~h}$ starvation, and their body weight $(\mathrm{g})$ and fork length $(\mathrm{cm})$ were individually measured with a digital balance (Kern, Germany) and tapeline, respectively. The growth performance of Siberian sturgeon juveniles was determined by calculating specific growth rate (SGR), feed conversion ratio (FCR), protein efficiency ratio (PER), and hepatosomatic index (HSI) based on the standard formulae as follows (Luo et al. 2010):

Specific growth rate $\left(\mathrm{SGR} ; \% \mathrm{~d}^{-1}\right)=[$ Ln final weight $(\mathrm{g})-\mathrm{Ln}$ initial weight $] /$ days $\times 100$

Food conversion ratio $(\mathrm{FCR})=$ feed consumption $(\mathrm{g}) /$ body weight gain $(\mathrm{g}) \times 100$

Condition factor $\left(\mathrm{CF} ; \mathrm{g} \mathrm{cm}^{-3}\right)=$ body weight $(\mathrm{g}) /$ fork length $\left(\mathrm{cm}^{3}\right) \times 100$

Hepatosomatic index $($ HSI; \%) $=$ liver weight $(\mathrm{g}) \times 100 /$ fish weight $(\mathrm{g})$

Five fish from each experimental replicate were randomly selected to collect the blood sample from the caudal vessels. The fish blood was then pooled together and heparinized for hematological studies. A drop of each fish's blood was also used to make blood smear for leucocyte differential count.

Hematological analysis

Counts of erythrocytes and leucocytes were performed based on the procedure suggested by Svobodova et al (1991) by mixing $20 \mu \mathrm{L}$ sample from each blood portion with $3980 \mu \mathrm{L}$ diluting fluids of red blood cells (RBCs) and white blood cells (WBCs), respectively. Cell counting was done under light microscope at magnification $100 \times$ using a Neubauer's counting chamber. Differential leucocyte counts were made from Leishman/Giemsa stained blood smears for $30 \mathrm{~min}$, after drying at ambient temperature and fixing in $96 \%$ ethanol for $30 \mathrm{~min}$ (Klontz 1994). Microscopic examination was carried out under compound microscope at magnification $400 \times$ to count at least 100 leukocytes (Khoshbavar-Rostami et al. 2006).

The blood hemoglobin $(\mathrm{Hb})$ concentration was determined based on the cyanmethemoglobin method using Drabkin's fluid (Drabkin 1950). An optical density (OD) was measured at $540 \mathrm{~nm}$ with a spectrophotometer and the hemoglobin level of blood was calculated as $\mathrm{g} \mathrm{dL}^{-1}$ by comparing with the standard cyanmethemoglobin based on the following formula:

$$
\text { Hemoglobin }=\frac{\mathrm{OD}_{\text {test }}}{\mathrm{OD}_{\text {standard }}} \times 0.251
$$


Hematocrit was also calculated based on the microhematocrit method of Snieszko (1960) by centrifuging capillary tubes for $5 \mathrm{~min}$ at $6000 \times \mathrm{g}$ with a microcentrifuge NF 048 . The derived hematological indices of mean corpuscular volume (MCV), mean corpuscular hemoglobin (MCH), and mean corpuscular hemoglobin concentration (MCHC) were calculated using the standard formulae (Seiverd 1964).

\section{Statistical analysis}

Levene's test was used to determine the homogeneity of variance, while the normality examined using the Kolmogorov-Smirnov test. The experimental parameters were subjected to one-way analysis of variance (oneway ANOVA), and comparisons between means were made by Tukey as a post-hoc test using the SPSS software (version 17). All data in the text are presented as mean \pm SD and statistical significance was accepted at the $p<0.05$ level. The broken line model was also applied according to the procedure of Robbins (1986) to estimate the $\mathrm{Zn}$ requirement of Siberian sturgeon.

\section{Results}

Growth performance

No mortality and abnormal behavior were observed in dietary treatments of Siberian sturgeon juveniles during the experimental period. The growth performance data are presented in Table 2.

The results indicated that dietary Zn level affected the growth performance of fish as final weight, and SGR and HSI values increased following the $\mathrm{Zn}$ level enhancement in experimental diets. The highest final weight was observed in $37.7 \mathrm{mg} \mathrm{kg}^{-1}$ which differed significantly with control $(p<0.05)$. The SGR showed a similar pattern of FW with the peak of $1.56 \pm 0.04 \% \mathrm{~d}^{-1}$ in the fish fed with $37.7 \mathrm{mg} \mathrm{kg}^{-1}$ dietary $\mathrm{Zn}$ level, beyond that it was not significantly differed.

On the other hand, FCR significantly declined with increasing dietary Zn supplementation with the least of $0.98 \pm 0.12$ in fish fed the diet containing $37.7 \mathrm{mg} \mathrm{Zn} \mathrm{kg}^{-1}(p<0.05)$. The CF deceased by increasing dietary $\mathrm{Zn}$ level up to $37.7 \mathrm{mg} \mathrm{kg}^{-1}$ diet and then increase with further supplementation. The CF was significantly decreased with increasing dietary $\mathrm{Zn}$ supplementation level, while no significant difference was found in the HSI of fish among the experimental treatments $(p>0.05)$.

Table 2 Growth performance and feed utilization of Siberian sturgeon (Acipenser baerii) juveniles, fed diets supplemented with graded zinc $(\mathrm{Zn})$

\begin{tabular}{lcclll}
\hline Dietary Zn level & FW $(\mathrm{g})$ & SGR $\left(\% \mathrm{~d}^{-1}\right)$ & FCR & CF $\left(\mathrm{g} \mathrm{cm}^{-1}\right)$ & HSI $(\%)$ \\
\hline $14.7 \mathrm{mg} \mathrm{Zn}$ & $50.86^{\mathrm{a}} \pm 2.65$ & $1.14^{\mathrm{a}} \pm 0.03$ & $2.27 \pm 0.18$ & $0.74^{\mathrm{c}} \pm 0.01$ & $2.39 \pm 0.05$ \\
$20.8 \mathrm{mg} \mathrm{Zn}$ & $53.07^{\mathrm{a}} \pm 3.52$ & $1.26^{\mathrm{a}} \pm 0.08$ & $1.95 \pm 0.19$ & $0.47^{\mathrm{b}} \pm 4.10$ & $2.44 \pm 0.02$ \\
$27.3 \mathrm{mg} \mathrm{Zn}$ & $64.07^{\mathrm{b}} \pm 3.92$ & $1.51^{\mathrm{b}} \pm 0.09$ & $1.14 \pm 0.16$ & $0.26^{\mathrm{a}} \pm 0.03$ & $2.67 \pm 0.05$ \\
$37.7 \mathrm{mg} \mathrm{Zn}$ & $65.34^{\mathrm{b}} \pm 2.38$ & $1.56^{\mathrm{b}} \pm 0.04$ & $0.98 \pm 0.12$ & $0.24^{\mathrm{a}} \pm 0.05$ & $3.03 \pm 0.03$ \\
$46.4 \mathrm{mg} \mathrm{Zn}$ & $61.74^{\mathrm{ab}} \pm 1.41$ & $1.47^{\mathrm{ab}} \pm 0.05$ & $1.23 \pm 0.10$ & $0.45^{\mathrm{b}} \pm 0.05$ & $3.81 \pm 0.04$ \\
\hline
\end{tabular}

Similar superscripts in each column show no significant difference between means for each treatment $(p>0.05)$

Final weight $(\mathrm{FW}, \mathrm{g})$

Specific growth rate $\left(\mathrm{SGR}, \% \mathrm{~d}^{-1}\right)=[$ Ln final weight $(\mathrm{g})-\mathrm{Ln}$ initial weight $] /$ days $\times 100$

Food conversion ratio $(\mathrm{FCR})=$ feed consumption $(\mathrm{g}) /$ body weight gain $(\mathrm{g})$

Condition factor $\left(\mathrm{CF}, \mathrm{g} \mathrm{cm}^{-3}\right)=$ body weight $(\mathrm{g}) /$ fork length $\left(\mathrm{cm}^{3}\right) \times 100$

Hepatosomatic index $($ HSI, \%) $=$ liver weight $(\mathrm{g}) \times 100 /$ fish weight $(\mathrm{g})$

${ }^{1}$ Mean \pm SD of three groups of fish $(n=3)$ with 20 fish per group except for HSI with 5 fish per group $(n=20$, except for HSI which $n=5$ ) 
Hematological parameters

Erythrocyte numbers of Siberian sturgeon juveniles were significantly $(p<0.05)$ enhanced with increasing dietary $\mathrm{Zn}$ supplementation from 14.7 to $37.7 \mathrm{mg} \mathrm{kg}^{-1}$ diet, while did not significantly changed thereafter (Table 3). A similar pattern was observed for $\mathrm{Hb}$ and hematocrit, and the highest levels were seen in fish fed $46.4 \mathrm{mg} \mathrm{Zn} \mathrm{kg}{ }^{-1}$. In contrast, $\mathrm{MCV}$ and $\mathrm{MCH}$ declined with increasing dietary $\mathrm{Zn}$ level with the minimum level in fish fed with the diet containing $37.7 \mathrm{mg} \mathrm{Zn} \mathrm{kg}^{-1}$ which shows the value of $507.33 \pm 3.48 \mathrm{fL}$ and $104.33 \pm 1.79 \mathrm{pg}$, respectively. However, no significant difference was found in the MCHC of fish fed with the supplemental $\mathrm{Zn}$ compared with those fed with the basal diet.

A significant $(p<0.05)$ increase was observed in leucocyte number of fish fed with the experimental diets (Table 4). Fish fed with control diet showed the least leucocyte count, while an increasing trend was recorded by increasing dietary $\mathrm{Zn}$ supplementation. All dietary $\mathrm{Zn}$ treatments induced significant increase in neutrophil and monocyte count of fish compared to the control treatment $(p<0.05)$. Conversely, the lymphocyte was significantly declined with increasing $\mathrm{Zn}$ supplementation to the basal diet $(p<0.05)$. The eosinophil percentage ranged between $1.00 \pm 0.76$ and $1.50 \pm 1.00$ with no significant differences among the treatments after 8 -week feeding trial $(p>0.05)$.

Dietary $\mathrm{Zn}$ requirement

The broken line regression model indicated that optimal dietary $\mathrm{Zn}$ level for growth maximization of Siberian sturgeon juveniles was estimated to be $29.15 \mathrm{mg} \mathrm{Zn} \mathrm{kg}^{-1}$ diet based on the final weight (Fig. 1). The count of erythrocytes of Siberian sturgeon was correlated $y=4.0735 x+349.27, R^{2}=0.9013$ ) with dietary Zn supplementation (Fig. 2). However, no break point was observed to estimate the $\mathrm{Zn}$ requirement of fish based on the erythrocyte numbers.

\section{Discussion}

The findings of the current research demonstrated that Siberian sturgeon juveniles have $\mathrm{Zn}$ requirement which could just be maintained through dietary supplementation. The lowest final weight and SGR observed in the fish fed with the basal diet, while they significantly enhanced by increasing $\mathrm{Zn}$ supplementation to the diets. The broken line analysis based on the final weight showed a requirement of $29.15 \mathrm{mg} \mathrm{kg}^{-1}$ diet. However, the dietary $\mathrm{Zn}$ requirement varies between other freshwater fish species, i.e., $20 \mathrm{mg} \mathrm{kg}^{-1}$ for channel catfish, Ictalurus punctatus (Gatlin and Wilson 1983), $15-30 \mathrm{mg} \mathrm{kg}^{-1}$ for rainbow trout, Oncorhynchus mykiss (Ogino and Yang 1978), 26-29 $\mathrm{mg} \mathrm{kg}^{-1}$ for tilapia, O. niloticus $\times$ O. aureus (Lin et al. 2008), 20-25 mg kg${ }^{-1}$ for red drum, Sciaenops ocellatus (Gatlin et al. 1991), and $48.7 \mathrm{mg} \mathrm{kg}^{-1}$ for juvenile Jian carp, C carpio var. Jian (Tan et al. 2011).

Table 3 Erythrocyte characteristics of Siberian sturgeon (Acipenser baerii) juveniles, fed diets supplemented with graded zinc

\begin{tabular}{lrrllll}
\hline $\begin{array}{l}\text { Dietary Zn } \\
\text { level }\end{array}$ & $\begin{array}{l}\mathrm{RBC}\left(\times 10^{3} \text { cell }\right. \\
\left.\mathrm{mm}^{-3}\right)\end{array}$ & $\mathrm{Hb}\left(\mathrm{g} \mathrm{dL}^{-1}\right)$ & \multicolumn{1}{l}{$\mathrm{HCT}(\%)$} & $\mathrm{MCV}(\mathrm{fl})$ & $\mathrm{MCH}(\mathrm{pg})$ & \multicolumn{1}{l}{$\begin{array}{l}\mathrm{MCHC} \\
\left(\mathrm{g} \mathrm{dL}^{-1}\right)\end{array}$} \\
\hline $14.7 \mathrm{mg} \mathrm{Zn}$ & $400.00^{1 \mathrm{a}} \pm 1.34$ & $4.50^{\mathrm{a}} \pm 0.55$ & $22.00^{\mathrm{a}} \pm 1.00$ & $549.67^{\mathrm{c}} \pm 2.42$ & $112.00^{\mathrm{b}} \pm 1.63$ & $20.19 \pm 0.38$ \\
$20.8 \mathrm{mg} \mathrm{Zn}$ & $434.00^{\mathrm{b}} \pm 1.12$ & $4.87^{\mathrm{ab}} \pm 0.40$ & $23.67^{\mathrm{ab}} \pm 1.07$ & $544.67^{\mathrm{bc}} \pm 4.20$ & $112.00^{\mathrm{b}} \pm 0.00$ & $20.73 \pm 0.44$ \\
$27.3 \mathrm{mg} \mathrm{Zn}$ & $467.67^{\mathrm{c}} \pm 1.24$ & $5.17^{\mathrm{bc}} \pm 0.46$ & $25.00^{\mathrm{b}} \pm 1.00$ & $534.00^{\mathrm{bc}} \pm 2.50$ & $110.00^{\mathrm{b}} \pm 1.00$ & $20.67 \pm 0.25$ \\
$37.7 \mathrm{mg} \mathrm{Zn}$ & $519.00^{\mathrm{d}} \pm 0.51$ & $5.43^{\mathrm{cd}} \pm 0.40$ & $26.33^{\mathrm{cd}} \pm 0.76$ & $507.33^{\mathrm{a}} \pm 3.48$ & $104.33^{\mathrm{a}} \pm 1.79$ & $20.48 \pm 0.13$ \\
$46.4 \mathrm{mg} \mathrm{Zn}$ & $523.67^{\mathrm{d}} \pm 1.09$ & $5.73^{\mathrm{d}} \pm 0.46$ & $27.67^{\mathrm{d}} \pm 0.76$ & $528.00^{\mathrm{b}} \pm 2.24$ & $109.00^{\mathrm{b}} \pm 1.63$ & $20.07 \pm 0.17$ \\
\hline
\end{tabular}

Similar superscripts in each column show no significant difference between means for each treatment $(p>0.05)$

$R B C$ red blood cell, $H b$ hemoglobin, $H C T$ hematocrit, $M C V$ mean corpuscular volume, $M C H$ mean cell hemoglobin, $M C H C$ mean corpuscular hemoglobin concentration

1 Mean \pm SD of three groups of fish $(n=3)$ with five fish per group 
Table 4 Leucocyte characteristics of Siberian sturgeon (Acipenser baerii) juveniles, fed diets supplemented with graded zinc

\begin{tabular}{llclcc}
\hline & Leucocyte $\left(\times 10^{3} \mathrm{~mm}^{-3}\right)$ & Neutrophils (\%) & Lymphocytes (\%) & Monocytes (\%) & Eosinophil (\%) \\
\hline $14.7 \mathrm{mg} \mathrm{Zn}$ & $7.97^{1 \mathrm{a}} \pm 0.01$ & $20.33^{\mathrm{a}} \pm 1.23$ & $76.67^{\mathrm{c}} \pm 1.23$ & $2.33^{\mathrm{a}} \pm 0.76$ & $1.00 \pm 0.76$ \\
$20.8 \mathrm{mg} \mathrm{Zn}$ & $9.20^{\mathrm{bc}} \pm 0.02$ & $24.00^{\mathrm{b}} \pm 1.00$ & $72.33^{\mathrm{b}} \pm 1.07$ & $3.67^{\mathrm{ab}} \pm 0.76$ & $1.33 \pm 0.76$ \\
$27.3 \mathrm{mg} \mathrm{Zn}$ & $10.10^{\mathrm{b}} \pm 0.02$ & $26.67^{\mathrm{c}} \pm 1.24$ & $67.33^{\mathrm{a}} \pm 1.23$ & $5.00^{\mathrm{b}} \pm 1.00$ & $1.50 \pm 1.00$ \\
$37.7 \mathrm{mg} \mathrm{Zn}$ & $11.63^{\mathrm{c}} \pm 0.03$ & $29.67^{\mathrm{d}} \pm 0.76$ & $65.00^{\mathrm{a}} \pm 1.32$ & $4.00^{\mathrm{b}} \pm 1.00$ & $1.33 \pm 0.76$ \\
$46.4 \mathrm{mg} \mathrm{Zn}$ & $12.33^{\mathrm{c}} \pm 0.04$ & $31.00^{\mathrm{d}} \pm 1.00$ & $64.00^{\mathrm{a}} \pm 1.00$ & $4.67^{\mathrm{b}} \pm 0.76$ & $1.00 \pm 0.76$
\end{tabular}

Similar superscripts in each column show no significant difference between means for each treatment $(p>0.05)$

${ }^{1}$ Mean \pm SD of three groups of fish $(n=3)$ with five fish per group

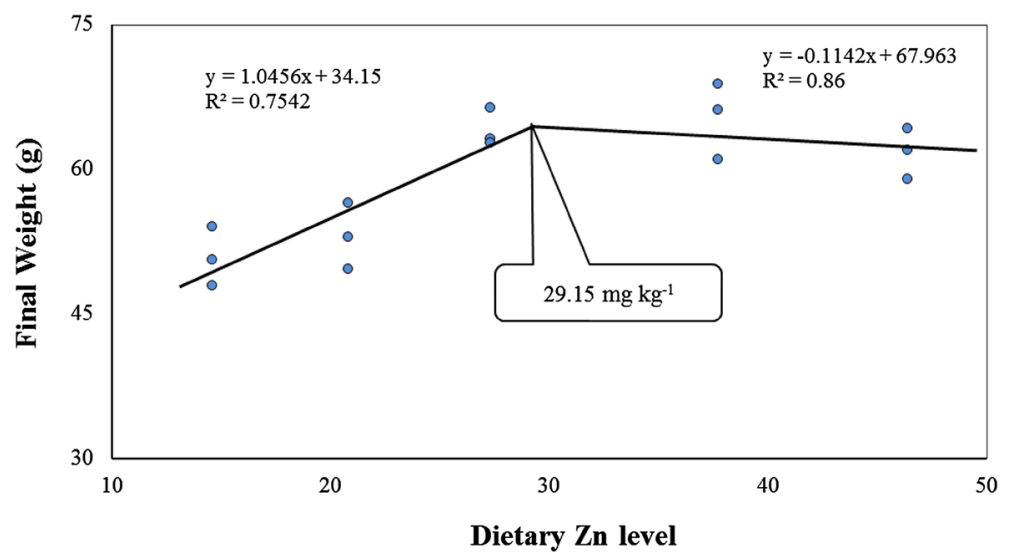

Fig. 1 Relationship between dietary Zn concentration and final weight in Siberian sturgeon (Acipenser baerii) juveniles, Acipenser baerii, based on the broken line regression analysis. Each point represents the mean of 20 fish in each replicate

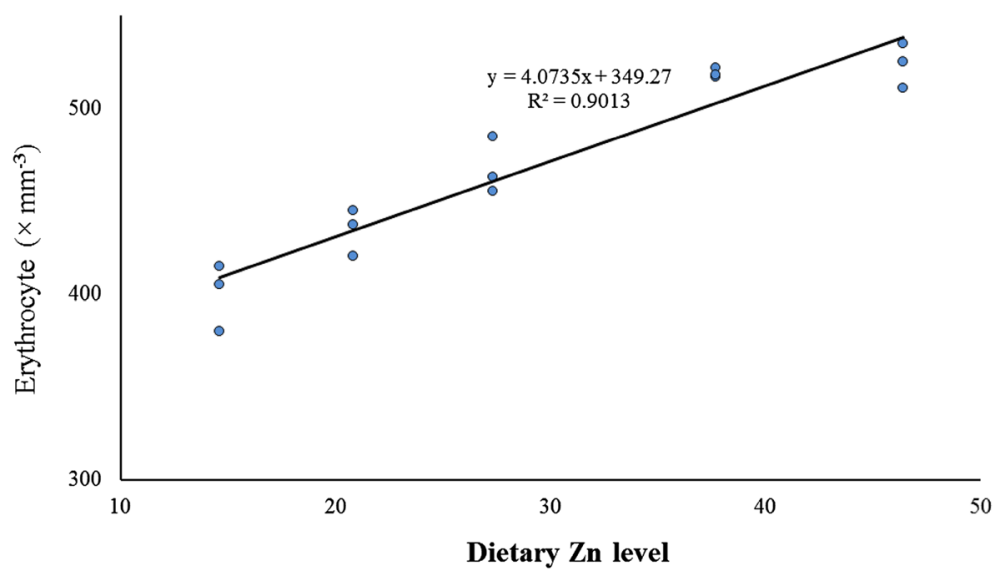

Fig. 2 Relationship between dietary Zn concentration and erythrocyte count in Siberian sturgeon (Acipenser baerii) juveniles, based on the regression analysis. Each point represents the mean of five fish in each replicate

Fish have similar cells types in their bloods with the same morphology and physiological functions found in mammals (Hrubec and Smith 2010). Although the normal ranges for biochemical key parameters have been identified for various raised fish species (Kopp et al. 2009; Xiaoyun et al. 2009; Satheeshkumar et al. 2011; Liang et al. 2012), there is scare information about the blood characteristics in Siberian sturgeon especially under culture conditions. Results of the present study illustrated that supplemental dietary Zn improves the hematological parameters of Siberian sturgeon. Erythrocyte counts were significantly increased by increasing $\mathrm{Zn}$ supplementation up to $37.7 \mathrm{mg} \mathrm{kg}^{-1}$ and then plateau thereafter. Despite extensive researches on different metabolic pathways, there is little information about the effect of dietary $\mathrm{Zn}$ on erythrocytes synthesis in fish. 
$\mathrm{Zn}$ is one of the essential elements affecting the protein synthesis in the erythrocytes, such as carbonic anhydrase and superoxide dismutase required for proper function of red blood cells (Hsieh et al. 2013; Hansch and Mendel 2009; Huang et al. 2015), which could explain the higher erythrocytes number of the fish fed diets with higher level of supplemental $\mathrm{Zn}$ in the present study.

$\mathrm{Zn}$ also plays an important role in hemoglobin synthesis by activating D-aminolevulinic acid (ALA) dehydrogenase, an enzyme essential for the porphobilinogen formation from two ALA molecules. In agreement with previous studies on other animals (El Hendy et al. 2001; Sobhanirad and Naserian 2012; Eze et al. 2015), results of the present research demonstrated that dietary $\mathrm{Zn}$ supplementation could significantly increase the $\mathrm{Hb}$ concentration in blood to $5.73 \pm 0.46$ resulting higher ability of blood to transfer oxygen from the gills to the rest of body. $\mathrm{Hb}$ is an iron-containing metalloprotein in the red blood cells of all vertebrates which its synthesis is strongly restricted with the activity of enzymes involved in the Fe metabolism, such as ceruloplasmin, a ferroxidase enzyme associated with possible oxidation of ferrous iron to ferric iron (Lall 2002; Harrison and Arosio 1996). Although exact route of iron from its entry to the ferroxidase site is unknown, $\mathrm{Zn}$ offers the advantages which can replace $\mathrm{Fe}^{2+}$ in iron-binding proteins without undergoing oxidation.

A controversial result was found in hematocrit of the fish fed different dietary $\mathrm{Zn}$ level compared to the other animals. Yadrick et al. (1989) expressed that supplemental dietary zinc decrease hematocrit, without changing the hemoglobin. In contrast, Bonham et al. (2003) stated that daily $40 \mathrm{mg} \mathrm{Zn}$ supplementation to the diet does not influence the blood parameters. In another investigation with 2-month-old rats, supplementation of $12 \mathrm{mg} \mathrm{Zn} \mathrm{kg}{ }^{-1}$ diet decreased the hemoglobin $85 \%$ compared to the control animals (Zaporowska and Wasilewski 1992). Current results are similar by those of Do Carmo et al. (2004) that established an increase in hematocrit with augmentation of dietary $\mathrm{Zn}$ level reaching to the $27.67 \pm 0.76 \%$, which show their higher capability of oxygen transfer from the gills to the tissues as well as more blood rheology and hemodynamics.

In the present study, MCV and MCH significantly decreased by increasing dietary $\mathrm{Zn}$ level from 14.7 to $37.7 \mathrm{mg} \mathrm{kg}^{-1}$, and then enhanced with further supplemental $\mathrm{Zn}$ to level of $46.4 \mathrm{mg} \mathrm{kg}^{-1}$ diet. However, no significant difference was found in the $\mathrm{MCHC}$ of the fish fed the elevated dietary $\mathrm{Zn}$ levels. When looking at RBC count, hematocrit, MCV, an MCHC of Siberian sturgeon reared in the current research, it can be concluded that increase of hematocrit is just connected with increase in the number of erythrocytes without any significant change in their hemoglobin concentration individually. Hrubec and Smith (2010) stated that more active fish have higher hemoglobin level, smaller erythrocytes, and lower MCV. Therefore, smaller MCV of the Siberian sturgeon fed the higher dietary $\mathrm{Zn}$ levels illustrated their higher ability to stand against hypoxia which commonly happens in the culture condition.

Antioxidant activities and contribution in the defense system is one of the important functions of the $\mathrm{Zn}$ in fish (Powell 2000). Zinc deficiency provokes growth retardation, cataract, skin erosion, high mortality, and oxidative damage through the effects of free radical action (Powell et al. 1994; Salgueiro et al. 2000; Ogino and Yang 1978) and alters the status of antioxidant enzymes and substances (Prasad et al. 1993). The mechanism by which $\mathrm{Zn}$ exerts its antioxidant action is not well defined. However, it has been suggested that it increases the synthesis of metallothionein, a zinc-binding protein present in erythrocytes involved in various aspects of zinc metabolism, which acts as a free radical scavenger (Prasad et al. 1993; Bales et al. 1994). In the present research, the number of erythrocytes significantly increased in higher zinc concentrations $(p<0.05)$, reaching to more than $40 \%$ increase in fish fed the $46.4 \mathrm{mg} \mathrm{kg}^{-1}$ diet compared to that in fish fed the basal diet.

Low dietary $\mathrm{Zn}$ concentration may characterize various diseases with aspects of an impaired immune response in fish representing more accurately reflects of tissue zinc. In vivo, Hu et al. (2001) observed that juvenile grouper had no difference in the non-specific immunity parameters (phagocytosis, complement, agglutination titer, and lysozyme activity) after feeding with zinc supplemented diets for 18 weeks. In vitro, zinc suppressed the lymphocyte proliferation of carp at a very low concentration (Cenini and Turner 1983; Ghanmi et al. 1989). Similarly, an 8-week feeding trial with Zn-supplemented diets had a significant effect on lymphocytes reduction which could be related to the fortification of innate immunity enhanced by the dietary $\mathrm{Zn}$ and less need for strengthening the humeral immunity.

On the other hand, result of the current study demonstrated an increase in the number of neutrophils as abundant type of granulocytes which form the essential part of innate immune system against pathogen infection. Previous studies illustrated that $\mathrm{Zn}$ may contribute to the host defense by interfering in the activation of neutrophils and subsequent oxidative burst (Finamore et al. 2008; Freitas et al. 2009), although the exact 
role of this trace element, either as an activator or inhibitor, remains a matter of contention between the researchers.

Open Access This article is distributed under the terms of the Creative Commons Attribution 4.0 International License (http:// creativecommons.org/licenses/by/4.0/), which permits unrestricted use, distribution, and reproduction in any medium, provided you give appropriate credit to the original author(s) and the source, provide a link to the Creative Commons license, and indicate if changes were made.

\section{References}

Abdolahnejad Z, Pourkazemi M, Khoshkholgh MR, Yarmohammadi M (2015) Expression of growth hormone gene during early development of Siberian sturgeon (Acipenser baerii). Mol Biol Res Comm 4:181-188

Bales CW, Di Silvestro RA, Currie KL, Plaisted CS, Joung H, Galanos AN, Lin PH (1994) Marginal zinc deficiency in older adults: responsiveness of zinc status indicators. J Am Coll Nutr 13:455-462

Beamesderfer RC, Farr RA (1997) Alternatives for the protection and restoration of sturgeons and their habitat. Environ Biol Fishes 48:407-417

Bonham M, O’Connor JM, Alexander HD, Coulter J, Walsh PM, McAnena LB, Downes CS, Hannigan BM, Strain JJ (2003) Zinc supplementation has no effect on circulating levels of peripheral blood leucocytes and lymphocyte subsets in healthy adult men. Br J Nutr 89:695-703

Bronzi P, Rosenthal H, Gessner J (2011) Global sturgeon aquaculture production: an overview. J Appl Ichthyol 27:169-175

Buentello JA, Goff JB, Gatlin IIIDM (2009) Dietary zinc requirement of hybrid striped bass, Morone chrysops $\times$ Morone saxatilis, and bioavailability of two chemically different zinc compounds. J World Aquac Soc 40:687-694

Cenini P, Turner RJ (1983) In vitro effects of zinc on lymphoid cells of the carp, Cyprinus carpio L. J Fish Biol 23:579-583

Chebanov MS, Karnaukhov GI, Galich EV, Chmir YN (2002) Hatchery stock enhancement and conservation of sturgeon, with an emphasis on the Azov Sea populations. J Appl Ichthyol 18:463-469

Chromcova L, Blahova J, Zivna D, Plhalova L, Casuscelli F, di Tocco L, Prokes M, Faggio C, Tichy F, Svobodova Z (2015) NeemAzal T/S-toxicity to early-life stages of common carp (Cyprinus carpio L.). Vet Med 60:23-30

Clearwater SJ, Farag AM, Meyer JS (2002) Bioavailability and toxicity of dietborne copper and zinc to fish. Comp Biochem Physiol C 132:269-313

Do Carmo E, Sá MV, Pezzato LE, Ferreira Lima MMB, De Magalhães Padilha P (2004) Optimum zinc supplementation level in Nile tilapia Oreochromis niloticus juveniles diets. Aquaculture 238:385-401

Drabkin DL (1950) The distribution of the chromoproteins, hemoglobin, myoglobin, and cytochrome $C$, in the tissues of different species, and the relationship of the total content of each chromoprotein to body mass. J Biol Chem 182:317-333

El Hendy HA, Yousef MI, El-Nagaa NIA (2001) Effect of dietary zinc deficiency on hematological and biochemical parameters and concentrations of zinc, copper, and iron in growing rats. Toxicology 167:163-170

Eze JI, Ayogu LC, Abonyi FO, Eze UU (2015) The beneficial effect of dietary zinc supplementation on anaemia and immunosuppression in Trypanosoma brucei infected rats. Exp Parasitol 154:87-92

Fazio F, Faggio C, Marafioti S, Torre A, Sanfilippo M, Piccione G (2012) Comparativestudy of haematological profile on Gobius niger in two different habitat sites: Faro Lake and Tyrrhenian Sea. Cah Biol Mar 53:213-219

Fazio F, Marafioti S, Torre A, Sanfilippo M, Panzera M, Faggio C (2013) Haematological and serum protein profiles of Mugil cephalus: effect of two different habitats. Ichthyol Res 60:36-42

Feng L, Tan LN, Liu Y, Jiang J, Jiang WD, Hu K, Li SH, Zhou XQ (2011) Influence of dietary zinc on lipid peroxidation, protein oxidation and antioxidant defence of juvenile Jian carp (Cyprinus carpio var. Jian). Aquac Nutr 17:e875-e882

Finamore A, Massimi M, Devirgiliis LC, Mengheri E (2008) Zinc deficiency induces membrane barrier damage and increases neutrophil transmigration in Caco-2 Cells. J Nutr 138:1664-1670

Fountoulaki E, Morgane H, Rigos G, Antigoni V, Mente E, Sweetman J, Nengas I (2010) Evaluation of zinc supplementation in European sea bass, Dicentrarchus labrax, juvenile diets. Aquac Res 41:208-216

Freitas M, PortoG Lima JLFC, Fernandes E (2009) Zinc activates neutrophils' oxidative burst. Biometals 23:31-41

Gatlin DM III, Phillips HF (1989) Dietary calcium, phytate and zinc interactions in channel catfish. Aquaculture 79:259-266

Gatlin DM III, Wilson RP (1983) Dietary zinc requirement of fingerling channel catfish. J Nutr 113:630-635

Gatlin DM III, O'Connell JP, Scarpa J (1991) Dietary zinc requirement of the red drum, Sciaenops ocellatus. Aquaculture 92:259-265

Ghanmi Z, Rouabhia M, Othmane O, Deschaux PA (1989) Effects of metal ions on cyprinid fish immune response: in vitro effects of $\mathrm{Zn} 21$ and $\mathrm{Mn} 21$ on the mitogenic response of carp pronephros lymphocytes. Ecotoxicol Environ Saf 17:183-189

Hamlin HJ, Michaels JT, Beaulaton CM, Main KL (2006) Refining feeding practices for hatchery production of Siberian sturgeon, Acipenser baeri. J World Aquac Soc 37:224-230

Hansch R, Mendel RR (2009) Physiological functions of mineral micronutrients (Cu, Zn, Mn, Fe, Ni, Mo, B, Cl). Curr Opin Plant Biol 12:259-266

Harrison PM, Arosio P (1996) The ferritins: molecular properties, iron storage function and cellular regulation. Biochim Biophys Acta 1275:161-203

Hidalgo MC, Exposito A, Palma JM, Higuera MDL (2002) Oxidative stress generated by dietary Zn-deficiency: studies in rainbow trout, Oncorhynchus mykiss. Int J Biochem Cell B 34:183-193 
Houng-Yung C, Yu-Chun C, Li-Chi H, Meng-Hsien C (2014) Dietary zinc requirements of juvenile grouper, Epinephelus malabaricus. Aquaculture 432:360-364

Hrubec TC, Smith SA (2010) Hematology of Fishes. In: Douglas J (ed) Schalm‘s veterinary hematology, 6th edn. Blackwell Publishing Ltd, Singapore, pp 994-1003

Hsieh SI, Castruita M, Malasarn D, Urzica E, Erde J, Page MD, Yamasaki H, Casero D, Pellegrini M, Merchant SS, Loo JA (2013) The proteome of copper, iron, zinc, and manganese micronutrient deficiency in Chlamydomonas reinhardtii. Mol Cell Proteom 12:65-86

Hu LC, Chen MS, Chen HY (2001) Dietary zinc for juvenile grouper Epinephelus malabaricus: requirements and immune responses. In: Gupta MV et al (eds) Book of abstracts, 6th Asian Fisheries Forum. Kaohsiung, Taiwan, p 47

Huang F, Jiang M, Wena H, Wua F, Liua W, Jb Tiana, Yang C (2015) Dietary zinc requirement of adult Nile tilapia, Oreochromis niloticus, fed semi-purified diets, and effects on tissue mineral composition and antioxidant responses. Aquaculture 439:53-59

Khoshbavar-Rostami HA, Soltani M, Hassan HMD (2006) Immune response of great sturgeon (Huso huso) subjected to long-term exposure to sublethal concentration of the organophosphate, diazinon. Aquaculture 256:88-94

Klontz GW (1994) Fish hematology. In: Stolen JS, Fletcher TC, Rowley AF, Kelikoff TC, Kaattari SL, Smith SA (eds) Techniques in fish immunology, vol 3. SOS Publications, Fair Haven, NJ, USA, pp 121-132

Kopp R, Mares J, Palíková M, Navrátil S, Kubíček Z, Ziková A, Hlávková J, Bláha L (2009) Biochemical parameters of blood plasma and content of microcystins in tissues of common carp (Cyprinus carpio L.) from a hypertrophic pond with cyanobacterial water bloom. Aquac Res 40:1683-1693

Kouřil J, Hamáčková J, Stupka Z, Mikodina EV, Sedova MA, Vachta R (2003) Effects of temperature on sensitivity of Siberian sturgeon (Acipenser baeri) to clove oil as anesthetic. International symposium, cold water aquaculture: start in the XXI: Century. Rosinformmagrotekh, St. Petersburg, p 111

Kucukbay Z, Yazlak H, Sahin N, Tuzcu M, Cakmak MN, Gurdogan F, Juturu V, Sahin K (2006) Zinc picolinate supplementation decreases oxidative stress in rainbow trout, Oncorhynchus mykiss. Aquaculture 257:465-469

Lall SP (2002) The minerals. In: Halver JE, Hardly RW (eds) Fish nutrition, 3rd edn. Academic, San Diego, pp 259-309

Liang JJ, Yang HJ, Liu YJ, Tian LX, Liang GY (2012) Dietary zinc requirement of juvenile grass carp, Ctenopharyngodon idella, based on growth and mineralization. Aquac Nutr 18:380-387

Lin YH, Jiang LC, Yen SS (2008) Dietary zinc requirements of juvenile hybrid tilapia, Oreochromis niloticus $\times$ O. aureus. J Fish Soc Taiwan 35:117-125

Lin S, Lin X, Yang Y, Li F, Luo L (2013) Comparison of chelated zinc and zinc sulfate as zinc sources for growth and immune response of shrimp, Litopenaeus vannamei. Aquaculture 406-407:79-84

Luo G, Xu J, Teng Y, Ding C, Yan B (2010) Effects of dietary lipid levels on the growth, digestive enzyme, feed utilization and fatty acid composition of Japanese sea bass (Lateolabrax japonicus) reared in freshwater. Aquac Res 41:210-219

Luo Z, Tan X, Zheng J, Chen Q, Liu C (2011) Quantitative dietary zinc requirement of juvenile yellow catfish, Pelteobagrus fulvidraco, and effects on hepatic intermediary metabolism and antioxidant responses. Aquaculture 319:150-155

Ogino C, Yang GY (1978) Requirement of rainbow trout for dietary zinc. Bull Jpn Soc Sci Fish 44:1015-1018

Powell SR (2000) The antioxidant properties of zinc. J Nutr 130(5):1447S-1454S

Powell SR, Hall D, Aiuto L, Wapnir RA, Teichberg S, Tortolani AJ (1994) Zinc improves postischemic recovery of isolated rat hearts through inhibition of oxidative stress. Am J Physiol 266:2497-2507

Prasad AS, Fitzgerald JT, Hess JW, Kaplan F, Pelen J, Dardenne M (1993) Zinc deficiency in elderly patients. Nutrition 9:218-224

Robbins KR (1986) A method, SAS program, and example for fitting the broken-line to growth data. University of Tennessee. Agricultural Experimental Station Research Report 86-09

Salgueiro MJ, Zubillaga M, Lysionek A, Sarabia MI, Caro R, De Paoli T, Hager A, Weill R, Boccio J (2000) Zinc as essential micronutrient: a review. Nutr Res 20:737-755

Satheeshkumar P, Ananthan G, Senthil Kumar D, Jagadeesan L (2011) Haematology and biochemical parameters of different feeding behaviour of teleost fishes from Vellar estuary, India. Comp Clin Pathol. doi:10.1007/s00580-011-1259-7

Seiverd CE (1964) Haematology for medical technologists. Lea and Febiger, Philadelphia

Snieszko SF (1960) Microhaematocrit as a tool in fishery research and management. Special Scientific Reports-Fisheries 341, the U. S. Fish and Wildlife Service, Washington

Sobhanirad S, Naserian AA (2012) Effects of high dietary zinc concentration and zinc sources on hematology and biochemistry of blood serum in Holstein dairy cows. Anim Feed Sci Technol 177:242-246

Svobodova Z, Pravda D, Palakova J (1991) Unified methods of hematological examination of fish. Research institute of fish culture and hydrobiology. Vodnany, Czech Republic

Tan LN, Feng L, Liu Y, Jiang J, Jiang WD, Hu K, Li SH, Zhou XQ (2011) Growth, body composition and intestinal enzyme activities of juvenile Jian carp (Cyprinus carpio var. Jian) fed graded levels of dietary zinc. Aquac Nutr 17:338-345

Trevisan R, Flesch S, Mattos JJ, Milani MR, Bainy ACD, Dafre AL (2014) Zinc causes acute impairment of glutathione metabolism followed by coordinated antioxidant defenses amplification in gills of brown mussels Perna perna. Comp Biochem Phys C 159:22-30

Waldman JR, Wirgin II (1997) Status and restoration options for Atlantic sturgeon in North America. Conserv Biol 12:631-638

Wei QW, Zou Y, Li P, Li L (2011) Sturgeon aquaculture in China: progress, strategies and prospects assessed on the basis of nation-wide surveys (2007-2009). J Appl Ichthyol 27:162-168

Williot P, Arlati G, Chebanov M, Gulyas T, Kasimov R, Kirschbaum F, Patriche N, Pavlovskaya LP, Poliakova L, Pourkazemi M, Kim Y, Zhuang P, Zholdasova I (2002) Status and management of Eurasian sturgeon: an overview. Int Rev Hydrobiol 87:483-506 
Xiaoyun Z, Mingyun L, Khalid A, Weinmin W (2009) Comparative of haematology and serum biochemistry of cultured and wild Dojo loach Misgurnus anguillicadatus. Fish Physiol Biochem 35:435-441

Yadrick MK, Kenney MA, Winterfeldt EA (1989) Iron, copper, and zinc status: response to supplementation with zinc or zinc and iron in adult females. Am J Clin Nutr 49:145-150

Zaporowska H, Wasilewski W (1992) Combined effect of vanadium and zinc on certain selected haematological indices in rats. Comp Biochem Physiol C 103:143-147 